\title{
Vitamin D with Calcium Supplementation Managing Glycemic Control with HbA1c and Improve Quality of Life in Patients with Diabetes
}

\author{
(1) Sanjana MEHTA ${ }^{1}$, (1) Parminder NAIN ${ }^{1 *}$, (1) Bimal K. AGRAWAL2, (1) Rajinder Pal SINGH³ \\ ${ }^{1}$ Maharishi Markandeshwar College of Pharmacy (Deemed to be University), Department of Pharmacy Practice, Haryana, India \\ 2Maharishi Markandeshwar Institute of Medical Science and Research (Deemed to be University), Department of Medicine, Haryana, India \\ 3Pancham Multi Speciality Hospital, Department of Medicine, Ludhiana, India
}

\begin{abstract}
Objectives: This study evaluates the effect of vitamin $D$ with calcium supplementation on glycemic control and quality of life (QoL) in patients with diabetes.

Materials and Methods: A prospective, observational, open-label randomized, controlled study was conducted on 150 type-2 patients with diabetes. A total number of patients were divided into three groups ( $n=50$ in each group) i.e. group 1 (patient on oral hypoglycemic agents), group 2 (oral hypoglycemic agents with vitamin D $60.000 \mathrm{IU} /$ week), and group 3 (oral hypoglycemic agents, vitamin D 60.000 IU/week along with daily calcium of $1.000 \mathrm{mg} /$ day). Biochemical estimation of fasting/random blood glucose (RBG), hemoglobin A1c (HbA1c), serum insulin and patient's QoL were analyzed using modified diabetes QoL (MDQoL)-17 questionnaire after 12 weeks of treatment. Data were analyzed using a student $t$-test (paired $t$-test)

Results: The majority of the patients were male (more than $50 \%$ ) with an average age of $50 \pm 6$ years having a diabetic history of more than 10 years and $\mathrm{HbA} 1 \mathrm{c}$ level $>10 \%$ in all three groups. After 12 weeks supplementation, the mean value of vitamin D was $25.73 \pm 6.2 \mathrm{ng} / \mathrm{mL}, 29.98 \pm 5.3 \mathrm{ng} / \mathrm{mL}$ and $62.71 \pm 7.8^{*} \mathrm{ng} / \mathrm{mL}$ in groups 1,2 , and 3 , respectively $(p<0.05)$ compared to baseline. A change in the mean value of HbA1c, in group $2(14.64 \pm$ 3.48 to $13.99 \pm 3.16 \%)$ and group $3(14.05 \pm 2.65$ to $12.04 \pm 2.21 \%)$ was also seen at the end of the study. Moreover, patients showed a positive effect of vitamin $D$ with calcium in group 3 with increased MDQoL, $30 \%$ of patients were in more than 70 score range.

Conclusion: The result of the study indicates that vitamin $\mathrm{D}$ supplementation with calcium significantly controlled or reduced $\mathrm{HbA} 1 \mathrm{c}$; fasting and RBG levels moreover improve QoL in type-2 patients with diabetes. It suggests that this combination can be considered a therapeutic supplement along with a primarily used anti-diabetic regimen.
\end{abstract}

Key words: Diabetes mellitus type-2, glycemic control, quality of life, vitamin D, calcium

\section{INTRODUCTION}

Diabetes mellitus is a chronic, serious, and growing metabolic disorder of the pancreatic gland, caused by relative or absolute insulin deficiency. It develops frequently after the age of 40 , therefore, it is known as "Adult - Onset Diabetes".' More than 62 million patients with diabetes have been currently diagnosed with the disease and it is the third leading cause of death. Worldwide the number will keep on increasing due to aging, population growth, and increasing prevalence of obesity or physical inactivity because of a sedentary lifestyle. ${ }^{2}$ Diabetes is considered a potential epidemic and India is also called "The Diabetes Capital of the World". ${ }^{3}$ According to the World Health Organization, the number of diabetic patients has risen from 108 million in 1980 to 422 million in 2014.4 International Diabetes Federation is expecting that there will be 578 million diabetics by 2030 and estimates to raise 700 million by $2045 .{ }^{5}$ Over the past few decades, an interesting angle to the pathophysiology of diabetes suggested a strong link of vitamin $D$ concentrations in the body with diabetes etiopathogenesis and vitamin $D$ deficiency is considered as a leading cause of this disease. ${ }^{6}$ 
Vitamin $D$ is required for normal insulin secretion and glucose tolerance. ${ }^{7}$ In various prospective observational studies, it has been found that low serum vitamin $D$ levels increase the risk of developing insulin resistance in diabetes. ${ }^{7}$ Moreover vitamin $D$ deficiency or insufficient calcium intake may modify the balance between the intracellular and extracellular $\beta$-cell calcium pools, resulting in disturbing normal insulin secretion. ${ }^{8}$ According to the pathogenesis of type-2 diabetes, the presence of vitamin $D$ receptors on the $\beta$-cells is responsible for insulin resistance by affecting calcium metabolism or $\beta$-cell function.,10 In addition, vitamin $D$ improves insulin sensitivity by attenuating the expression of pro-inflammatory cytokines. ${ }^{11}$ Vitamin D deficiency is prevailing in epidemic proportions worldwide and specifically all over the Asian and European continent with a prevalence of $70-100 \%$ in the general population. ${ }^{12}$ Thus, we found it important to elucidate the level of vitamin $D$ and the potential role of vitamin $D$ supplementation with or without calcium in improving glycemic control and quality of life ( $Q \circ L)$ in type-2 patients with diabetes. ${ }^{13}$

\section{MATERIALS AND METHODS}

This study was a prospective, observational; open-label randomized controlled study of 12 weeks duration, to evaluate the effect of vitamin $D$ supplementation with or without calcium on the glycemic profile in 150 patients of type-2 diabetes mellitus. Patients were selected from outpatient and inpatient departments of medicine in a tertiary care hospital for the period from November 2020 to March 2021 (including 2 months of recruitment). The Institutional Ethics Committee (IEC) Maharishi Markandeshwar Institute of Medical Science and Research approval was obtained (project no: IEC-1565) before the conduct of the study. Written informed consent was signed from all patients before participation in the study. All biochemical test parameters were assessed after one day of the last administered dose of supplements. Patients were selected based on inclusion and exclusion criteria.

\section{Inclusion criteria}

Adult patients (40-60 years) having type-2 diabetes for at least 10 years, who were taking one or two oral hypoglycemic agents regularly, hemoglobin $\mathrm{A} 1 \mathrm{c}(\mathrm{HbA1c})>10 \%$ and low vitamin $\mathrm{D}$ levels $(\leq 24 \mathrm{ng} / \mathrm{mL})$

\section{Exclusion criteria}

Patients with other types of diabetes, current or previous use of vitamin $D$ or multivitamins, pregnant women, patients with chronic kidney disease stage 5; diabetic ketoacidosis, liver cirrhosis, hypothyroidism/hyperthyroidism, osteoporosis and patients with a body mass index (BMI) more than $30 \mathrm{~kg} / \mathrm{m}^{2}$ were excluded from the study.

\section{Study design}

The sample size was calculated based on the data obtained from previous studies using power and precision software. A total of 150 patients were identified according to inclusion and exclusion criteria and were divided into three groups ( $n=50 \mathrm{per}$ group) by simple randomization.
At the baseline of the study, after detailed patient history and clinical examination, routine investigations were done to exclude any comorbidity. The baseline values of fasting blood glucose (FBG), random blood glucose (RBG), HbA1c, fasting serum insulin, serum calcium, serum phosphate and vitamin $D$ levels were obtained on the day of enrollment to the study and follow-up of these patients were up to 12 weeks. FBG/RBG levels were observed every $4^{\text {th }}$ week, whereas $\mathrm{HbA1c}$, serum vitamin D, and serum calcium levels were recorded at the end of the study (Figure 1). During the study, the drugs were prescribed by guidelines, and patients were instructed not to change their oral anti-diabetic medicines, diet and lifestyle.The QoL of selected patients with diabetes were assessed by the validated questionnaire modified diabetes QoL (MDQoL)-17, which consists of 17 questions comprising seven domains including role limitations due to physical health problems, physical functioning, social functioning, and emotional wellbeing, role limitations due to personal or emotional problems, general health perceptions and energy or fatigue (Table 1). ${ }^{14}$ The information was obtained and entered in a case report form after obtaining their consent. The patients were scored in the range between 0 and 100, where 0 is the minimum and 100 is the maximum score. For comparison and analysis, the QoL score of MDQoL-17 was expressed as the percentage of the total possible score achieved. The patients with having an MDQoL score of less than 50 had a poor QoL, a score between 50-70 had a moderate QoL and a more than 70 score had a better QoL.

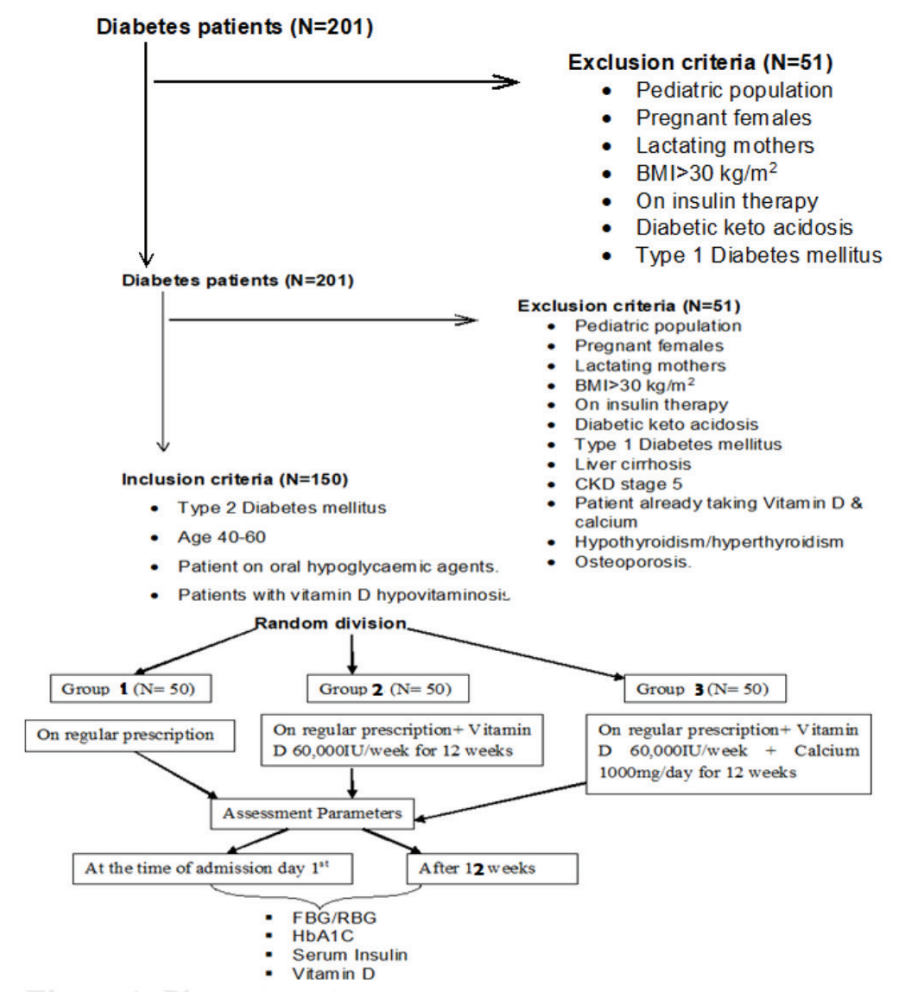

Figure 1. Plan of work

FBG: Fasting blood glucose, RBG: Random blood glucose, HbA1c: Hemoglobin A1c 


\section{Statistical analysis}

The data were normally distributed according to KolmogorovSmirnov normality test.

Statistical methods were used to determine the differences among the variables under study. The parametric data were analyzed using paired Student $t$-test followed by Dunnett's test into consideration for the special structure of comparing treatment against control, yielding narrower confidence intervals. Statistical analysis was done using SPSS software version 23 with $p<0.05$ considered statistically significant.

\section{RESULTS}

Demographic data of 150 type-2 diabetic patients who were divided into three groups based on the study protocol revealed

\section{Table 1. Modified diabetes quality of life -17 questionnaire}

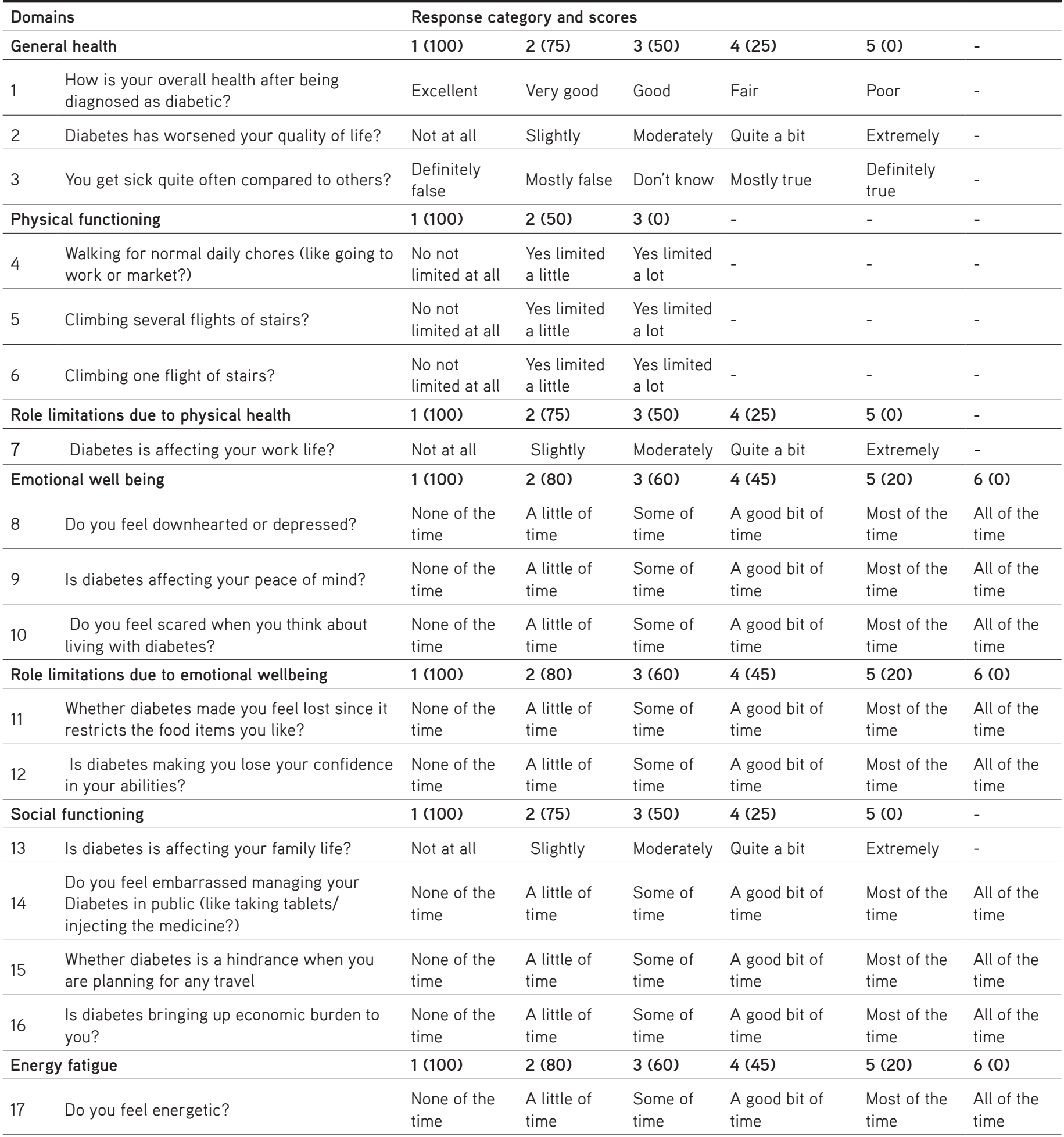


that most patients affected by diabetes were male (more than $50 \%$ ) compared to females in all three groups. The mean age of the patient found in this study was $50 \pm 6.2$ years and BMI was $\left(27.7 \pm 0.6 \mathrm{~kg} / \mathrm{m}^{2}\right)$. All the patients were having type- 2 diabetes mellitus for more than 10 years and were taken from both in patient $(14 \pm 2 \%)$ and out-patient ( $84 \pm 4 \%$ ) departments in all three groups. No statistical difference was found in all three groups of patients. The patient with diabetes was admitted to the hospital, not due to diabetes or its complication. They were admitted to the hospital due to other illnesses and diabetes was found as a comorbid condition (Table 2). Drug prescribing patterns in recruited patients were studied and analyzed on the basis of symptoms and existing comorbid conditions. The major categories of drugs prescribed were oral hypoglycemic agents (monotherapy or dual therapy) with anti-hypertensive, anti-platelets, statins, and antibiotics.

The mean FBG decreased $(170 \pm 13.11 \mathrm{mg} / \mathrm{dL}$ to $162 \pm 26.23$ $\mathrm{mg} / \mathrm{dL}$ ) with oral hypoglycemic agents such as sulfonylureas and biguanides in group 1, whereas in group 2 when oral hypoglycemic agents were given with vitamin $D$ supplementation FBG levels decreased $(176 \pm 09.54 \mathrm{mg} / \mathrm{dL}$ to $169 \pm 11.72 \mathrm{mg} / \mathrm{dL})$ and in group 3 the level of FBG was at maximum decline i.e. (167 $\pm 17.22 \mathrm{mg} / \mathrm{dL}$ to $139 \pm 11.59 \mathrm{mg} / \mathrm{dL}$ ) with calcium and vitamin $\mathrm{D}$ supplementation.

The RBG post supplementation was decreased non-significantly (328.45 $\pm 19.49 \mathrm{mg} / \mathrm{dL}$ to $249.45 \pm 18.43 \mathrm{mg} / \mathrm{dL}$ ) in group 2, whereas a statistically significant $(p<0.05)$ decrease was seen in group 3 (305.10 $\pm 17.45 \mathrm{mg} / \mathrm{dL}$ to $\left.202.10 \pm 12.37^{*} \mathrm{mg} / \mathrm{dL}\right)$.

The serum insulin levels were also found to be on the lower side (30 $\pm 11.27 \mu \mathrm{lU} / \mathrm{mL}$ to $29 \pm 16.75 \mu \mathrm{lU} / \mathrm{mL}$ ) in group 1 , whereas in group 2 after supplementation of vitamin $D$ without calcium the serum insulin levels were $(28 \pm 9.65 \mu \mathrm{lU} / \mathrm{mL}$ to $24.67 \pm 11.95$ $\mu \mathrm{lU} / \mathrm{mL})$ but statistically significant $(p<0.05)$ decrease $(29 \pm$ $7.39 \mu \mathrm{lU} / \mathrm{mL}$ to $20.76 \pm 6.23^{*} \mu \mathrm{lU} / \mathrm{mL}$ ) was seen in group 3 post supplementation (Table 3 ).
The mean baseline serum vitamin $D$ levels for group 1, group 2 , and group 3 were $25.78 \pm 5.3 \mathrm{ng} / \mathrm{mL}, 28 \pm 4.1 \mathrm{ng} / \mathrm{mL}$ and $28 \pm 5.3 \mathrm{ng} / \mathrm{mL}$, respectively. The levels of vitamin $D$ were significantly $(p<0.05)$ increased $62.71 \pm 7.8^{*} \mathrm{ng} / \mathrm{mL}$ in group 3 , after giving vitamin $D$ with calcium supplementation for three months. However, a non-significant increase in mean serum vitamin $\mathrm{D}$ level was observed in group 1 and group 2 compared to baseline after three months i.e. $25.73 \pm 6.2 \mathrm{ng} / \mathrm{mL}$ and 29.98 $\pm 5.3 \mathrm{ng} / \mathrm{mL}$, respectively (Figure 2 ).

When calcium was given with vitamin $D$ (group 3), a decrease in $\mathrm{HbA} 1 \mathrm{c}$ levels from baseline i.e. $14.05 \pm 2.65 \%$ to $12.04 \pm 2.21 \%$ was observed after three months of supplementation. However, there was a slight increase in HbA1c levels (14.64 $\pm 3.2 \%$ ) in group 1 and a non-significant decrease in levels of HbA1C (13.99 $\pm 3.16 \%$ ) was observed in group 2 with respect to baseline parameters $(14.93 \pm 2.4 \%)$ and $(14.64 \pm 3.48 \%)$, respectively (Figure 3).

The mean calcium levels among individuals of group 2 revealed a non-significant increase $(9.06 \pm 0.63 \mathrm{mg} / \mathrm{dL}$ to $9.1 \pm 0.49 \mathrm{mg} /$ $\mathrm{dL}$ ) from the baseline level among type-2 patients with diabetes. In group 3, the levels of serum calcium after supplementation for 3 months were found significantly ( $p<0.05)$ increase $(10.1 \pm$ $0.71^{*} \mathrm{mg} / \mathrm{dL}$ ) compared to baseline $(8.7 \pm 0.54 \mathrm{mg} / \mathrm{dL})$, while no change was observed in mean serum calcium levels in group 1 from ( $8.3 \pm 0.42 \mathrm{mg} / \mathrm{dL}$ to $8.41 \pm 0.51 \mathrm{mg} / \mathrm{dL}$ ) (Table 3). Vitamin D supplementation gradually increased phosphate levels ( $3.7 \pm$ $0.25 \mathrm{mg} / \mathrm{dL})$ and $(3.4 \pm 0.51 \mathrm{mg} / \mathrm{dL})$ compared to their respective mean baseline levels $(3.3 \pm 0.43 \mathrm{mg} / \mathrm{dL})$ and $(3.1 \pm 0.33 \mathrm{mg} / \mathrm{dL})$ in group 2 and 3 (Table 3 ).

After supplementation for 3 months, only $2 \%$ of patients in group -1 and $5 \%$ patients of group-2 experienced a better QoL, but nearly $20 \%$ of the patients from group 3 scored more than 70 in MDQoL scoring. Moreover, the number of patients scoring less than 50 score remains unchanged in group 1, whereas compared to baseline scores of poor QoL class a decrease of

Table 2. Demographic data of study population

\begin{tabular}{|c|c|c|c|c|}
\hline \multirow{2}{*}{ Serial no } & \multirow{2}{*}{ Parameters } & \multicolumn{3}{|c|}{ Population $(n=150)$} \\
\hline & & Group $1(n=50)$ & Group $2(n=50)$ & Group $3(n=50)$ \\
\hline \multirow{3}{*}{1} & Age & & & \\
\hline & $-41-50$ & $46 \%(n=23)$ & $48 \%(n=24)$ & $56 \%(n=28)$ \\
\hline & $-51-60$ & $54 \%(n=27)$ & $52 \%(n=26)$ & $44 \%(n=22)$ \\
\hline \multirow{3}{*}{2} & Gender & & & \\
\hline & - Male & $58 \%(n=29)$ & $62 \%(n=31)$ & $54 \%(n=27)$ \\
\hline & - Female & $42 \%(n=21)$ & $38 \%(n=19)$ & $46 \%(n=23)$ \\
\hline \multirow[t]{2}{*}{3} & BMI $\left(\mathrm{kg} / \mathrm{m}^{2}\right)$ & $26.9 \pm 0.5$ & $28.9 \pm 0.7$ & $27.2 \pm 0.8$ \\
\hline & Duration of type-2 DM & & & \\
\hline \multirow[t]{3}{*}{4} & - 10-15 years & $44 \%(n=22)$ & $42 \%(n=21)$ & $46 \%(n=23)$ \\
\hline & $-15-20$ years & $56 \%(n=28)$ & $58 \%(n=29)$ & $54 \%(n=27)$ \\
\hline & Type of patient & & & \\
\hline \multirow[t]{2}{*}{5} & - In patient & $12 \%(n=6)$ & $16 \%(n=8)$ & $14 \%(n=7)$ \\
\hline & - Out patient & $88 \%(n=44)$ & $84 \%(n=42)$ & $86 \%(n=43)$ \\
\hline
\end{tabular}

BMI: Body mass index, DM: Diabetes mellitus 
$5 \%$ and $18 \%$ was seen in groups 2 and 3, respectively, post supplementation. However, gradual changes have been seen in moderate QoL score i.e. 2\% of patients experienced an improvement in their QoL in groups 1 and 3, respectively, after 3 months of supplementation. This improvement is due to proper adherence to oral hypoglycemic agents and vitamin $D$ with or without calcium supplementation (Table 4).

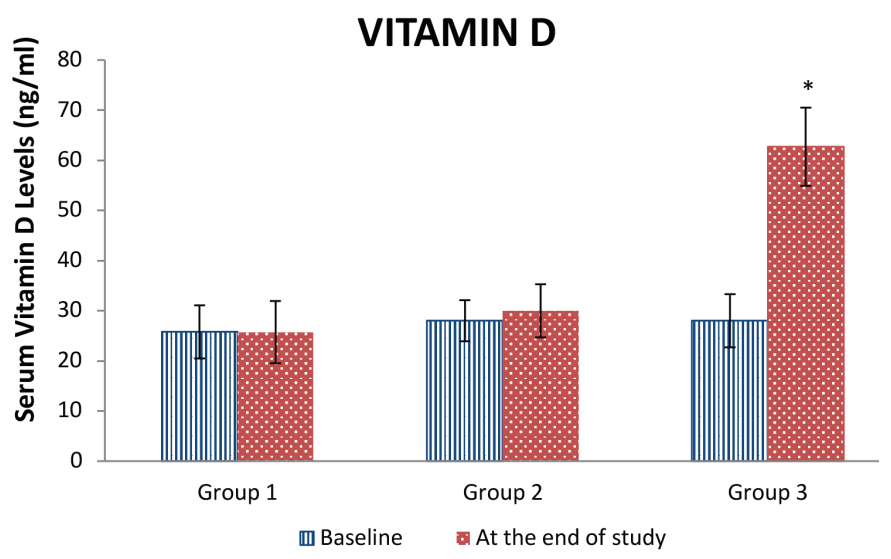

Figure 2. Serum vitamin $D$ concentrations at baseline and at the end of the study

${ }^{*} p<0.05$ was significant when compared with baseline value

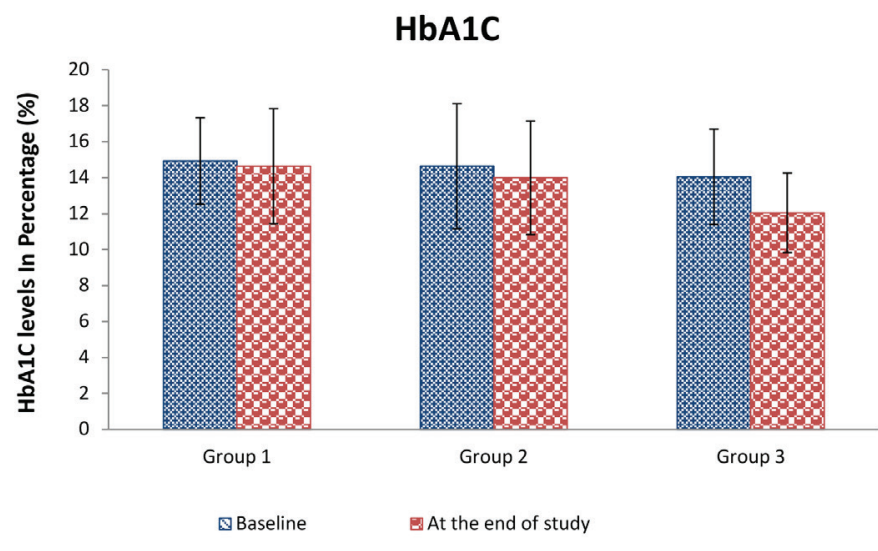

Figure 3. Serum HbA1c concentrations at baseline and at the end of the study

HbA1c: Hemoglobin A1c

\section{DISCUSSION}

In this study, we investigated the relationship of diabetes with respect to glycemic profile. Our study results revealed that males are most frequently affected by type-2 diabetes compared to females. Our study results are similar to the previous study by Bahendeka et al. ${ }^{14}$ has shown the prevalence of diabetes among males (1.6\%) is more dominant than in females $(1.1 \%)$. Sedentary lifestyle is considered as a reason for increased body fat, increased BMI, and increasing the probability of occurrence of metabolic diseases like type-2 diabetes mellitus, dyslipidemia, and hypertension. ${ }^{15}$ Because of our study patients having BMl-25-29 $\mathrm{kg} / \mathrm{m}^{2}$ and this lead to the progression of diabetes. Another major reason behind the increasing trend of diabetes type- 2 is vitamin $D$ deficiency. Various studies have shown that vitamin $D$ stimulates the absorption of intestinal calcium by increasing the reabsorption of calcium from the distal tubule and by stimulating calcium mobilization from bone, whereas vitamin $D$ also helps in phosphorous absorption by stimulating bone mobilization. ${ }^{16}$ Asian and European populations are found to be vitamin D-deficient. 12,17 Thus, prescribing vitamin $\mathrm{D}$ and calcium supplementation to diabetes patients perhaps helps manage glycemic control in patients with diabetes. Therefore, we evaluated the patients to measure the effect of vitamin $D$ and calcium after oral vitamin $D$ supplementation of $60.000 \mathrm{lU} /$ week without and with calcium supplementation of $1000 \mathrm{mg} /$ day for 12 weeks. However, calcium supplementation alone did not find any therapeutic effect on glucose levels, insulin secretion or $\mathrm{HbA1c}$ levels. ${ }^{18}$ Vitamin $\mathrm{D}$ controls insulin secretion indirectly and normalizes the extracellular calcium by ensuring normal calcium flux through cell membranes. ${ }^{19}$ Therefore, combination therapy of vitamin $D$ and calcium was found to be significantly more effective in managing the glycemic profile of study participants than vitamin $D$ or calcium as monotherapy. We also found decreased mean baseline serum vitamin $D$ levels in patients with diabetes and our results are similar to Scragg et al. ${ }^{20}$, who also stated that there was a strong inverse association between diabetes and low levels of vitamin $D$, whereas normalizing these levels will result in $55 \%$ relative reduction in the risk of developing type- 2 diabetes mellitus. Numerous studies have also confirmed the effects of vitamin D supplementation on glucose metabolism.19,21 Present study results follow previous studies. Reduction of FBG,

Table 3. Blood biochemical parameters before and after the supplementation of vitamin $D$ and serum calcium

\begin{tabular}{|c|c|c|c|c|c|c|c|}
\hline \multirow[b]{2}{*}{$\begin{array}{l}\text { Serial } \\
\text { no }\end{array}$} & \multirow[b]{2}{*}{$\begin{array}{l}\text { Biochemical parameters } \\
\text { and units }\end{array}$} & \multicolumn{2}{|l|}{ Group $1(n=50)$} & \multicolumn{2}{|l|}{ Group $2(n=50)$} & \multicolumn{2}{|c|}{ Group $3(n=50)$} \\
\hline & & $\begin{array}{l}\text { Baseline } \\
\text { values }\end{array}$ & $\begin{array}{l}\text { Values after } 3 \\
\text { months } \\
\text { (mean } \pm \text { SD) }\end{array}$ & $\begin{array}{l}\text { Baseline } \\
\text { values }\end{array}$ & $\begin{array}{l}\text { Values after } 3 \\
\text { months } \\
\text { (mean } \pm \text { SD) }\end{array}$ & $\begin{array}{l}\text { Baseline } \\
\text { values }\end{array}$ & $\begin{array}{l}\text { Values after } 3 \\
\text { months } \\
\text { (mean } \pm \text { SD) }\end{array}$ \\
\hline 1 & Fasting blood glucose (mg/dL) & $170 \pm 13.11$ & $162 \pm 26.23$ & $176 \pm 09.54$ & $169 \pm 11.72$ & $167 \pm 17.22$ & $139 \pm 11.59$ \\
\hline 2 & Random blood glucose (mg/dL) & $308.36 \pm 18.26$ & $287.36 \pm 13.65$ & $328.45 \pm 19.49$ & $249.45 \pm 18.43$ & $305.10 \pm 17.45$ & $202.10 \pm 12.37^{*}$ \\
\hline 3 & Fasting serum insulin $(\mu \mathrm{lU} / \mathrm{mL})$ & $30 \pm 11.27$ & $29 \pm 16.75$ & $28 \pm 9.65$ & $24.67 \pm 11.95$ & $29 \pm 7.39$ & $20.76 \pm 6.23^{\star}$ \\
\hline 4 & Serum calcium (mg/dL) & $8.3 \pm 0.42$ & $8.41 \pm 0.51$ & $9.06 \pm 0.63$ & $9.1 \pm 0.49$ & $8.7 \pm 0.54$ & $10.1 \pm 0.71^{\star}$ \\
\hline 5 & Serum phosphate (mg/dL) & $2.9 \pm 0.47$ & $3.1 \pm 0.39$ & $3.3 \pm 0.43$ & $3.7 \pm 0.25$ & $3.1 \pm 0.33$ & $3.4 \pm 0.51$ \\
\hline
\end{tabular}

$p<0.05$ was significant when compared with baseline value. SD: Standard deviation 
Table 4. Quality of life on basis of MDQoL scoring

\begin{tabular}{|c|c|c|c|c|c|c|c|}
\hline \multirow[b]{2}{*}{ QoL score } & \multirow{2}{*}{$\begin{array}{l}\text { Classification on basis } \\
\text { of MDQoL scoring }\end{array}$} & \multicolumn{2}{|c|}{ Group $1(n=50)$} & \multicolumn{2}{|c|}{ Group $2(n=50)$} & \multicolumn{2}{|c|}{ Group $3(n=50)$} \\
\hline & & (Baseline) & (After 3 months) & (Baseline) & $\begin{array}{l}\text { (After } 3 \\
\text { months) }\end{array}$ & (Baseline) & $\begin{array}{l}\text { (After } 3 \\
\text { months) }\end{array}$ \\
\hline Less than 50 & Poor QoL & $54 \%$ & $54 \%$ & $56 \%$ & $51 \%$ & $60 \%$ & $42 \%$ \\
\hline $50-70$ & Moderate QoL & $28 \%$ & $26 \%$ & $32 \%$ & $32 \%$ & $30 \%$ & $28 \%$ \\
\hline More than 70 & Better QoL & $18 \%$ & $20 \%$ & $12 \%$ & $17 \%$ & $10 \%$ & $30 \%$ \\
\hline
\end{tabular}

MDQoL: Modified diabetes quality of life

RBG, and $\mathrm{HbA} 1 \mathrm{c}$ after administration of vitamin $\mathrm{D}$ along with calcium; thus, managing glycemic control. ${ }^{21,22}$ Initially, serum calcium levels were tested to rule out hypercalcemia due to supplementation but the concentration of serum calcium was lower in patients with diabetes. Previous studies have also shown an inverse correlation between calcium and disease progression. ${ }^{23}$ These levels gradually began to increase after supplementation. However, the mean levels of calcium remained within the normal range at the end of the study, no hypercalcemia was found because of supplementation and our study results followed previous studies. ${ }^{22}$ Results of this study also suggest that the mean level of phosphate was in the normal range yet they were slightly increased from baseline parameters, which are similar to previous studies. ${ }^{24}$ The reason behind this increase irrespective of the medication and supplementation, is usually caused by a kidney problem associated with natural diabetes progression. ${ }^{24,25}$ The present study also assessed the QoL in patients with diabetes on the basis of various domains including physical and emotional wellbeing, mental state, and social functioning. We observed an inverse correlation between QoL and disease progression, it is suggesting that progression in diabetes has a negative impact on QoL. Results were supported by previous studies which stated that QoL was way better in patients at a younger age without complications, with a BMI of $\left\langle 18.4 \mathrm{~kg} / \mathrm{m}^{2}\right.$ and $\mathrm{HbA} 1 \mathrm{c}$ level between $7.1-8.0 \% .^{26,27}$ Diabetic patients with a diabetic history of more than 10 years were found to have a poor QoL in this study, whereas, the MDQoL score for the patients on vitamin $D$ with calcium supplementation along with diabetic therapy was improved than the patients on oral hypoglycemic agents only. This may be attributed to the fact that using vitamin $\mathrm{D}$ with calcium as an adjuvant therapy gives better glycemic control and improves the QoL and decreases the rate of disease progression along with other diabetic complications. ${ }^{28}$

\section{Study limitations}

The small sample size and time constraints were the limitations of our study that impacted our results.

\section{CONCLUSION}

The study indicates that the administration of vitamin $D$ with calcium supplementation in type-2 patients with diabetes significantly improved QoL by controlling or reducing $\mathrm{HbA} 1 \mathrm{C}$, fasting, and RBG levels improved in patients with diabetes. Therefore the study suggests that vitamin $D$ and calcium can be considered add-on therapeutic supplements along with other anti-diabetic regimens for managing diabetic-related consequences and other diabetic complications.

\section{ACKNOWLEDGEMENTS}

We would like to acknowledge the staff of Pancham MultiSpecialty hospitals for their kind support and cooperation. We are thankful for the management of Maharishi Markandeshwar (Deemed to be University), Mullana (Ambala), India for encouragement and providing necessary facilities and support.

\section{Ethics}

Ethics Committee Approval: The Institutional Ethics Committee (IEC) Maharishi Markandeshwar Institute of Medical Science and Research approval was obtained (project no: IEC-1565) before the conduct of the study.

Informed Consent: Written informed consent was signed from all patients before participation in the study.

Peer-review: Externally peer-reviewed.

\section{Authorship Contributions}

Surgical and Medical Practices: B.K.A., R.P.S., Concept: S.M., P.N., B.A.K., Design: S.M., P.N., B.A.K., Data Collection or Processing: S.M., P.N., Analysis or Interpretation: S.M., P.N., Literature Search: S.M., P.N., Writing: S.M., P.N., B.K.A.

\section{REFERENCES}

1. Kaveeshwar SA, Cornwall J. The current state of diabetes mellitus in India. Australas Med J. 2014;7:45-48.

2. Batra HS, Sampath S, Kumar SA, Kumar AVSA, Mayar N. Study of vitamin $\mathrm{D}$ supplementation in type 2 diabetes mellitus. Int $\mathrm{J}$ Contemp Med Res. 2019;6:H5-H9

3. Rajhans PA, Kulkarni PY, Kelkar DS, Jog SA, Ranade G, Utpat S, Hande $V$. Effect of diabetes on severity of illness, length of hospital stay and mortality among patients brought by emergency medical system (EMS). Int J Med Public Health. 2017;7:156-161.

4. Sandhu RK, Sharma G, Nayyar SB, Gupta M. To study the efficacy and safety of vitamin $D$ as an add-on therapy in patients of type 2 diabetes mellitus on oral antidiabetic drugs. Int $\mathrm{J}$ Basic Clin Pharmacol. 2015;4:1276-1280.

5. Williams R, Colagiuri S, Almutairi R, Montoya P, Basit A, Beran D. IDF Diabets Atlas, $9^{\text {th }}$ edition 2019. International Diabetes Federation; 2019.

6. Mezza T, Muscogiuri G, Sorice GP, Prioletta A, Salomone E, Pontecorvi A, Giaccari A. Vitamin D deficiency: a new risk factor for type 2 diabetes? Ann Nutr Metab. 2012;61:337-348. 
7. Amirasgari F, Torkfar S, Rezazadeh S, Farzaneh M, Tajik E. Effect of vitamin $D$ on glucose homeostasis, sensitivity and insulin resistance in type 2 diabetes. Curr Res Diabetes Obes J. 2019;11:555810.

8. Norman AW, Frankel JB, Heldt AM, Grodsky GM. Vitamin D deficiency inhibits pancreatic secretion of insulin. Science. 1980;209:823-825.

9. Chertow BS, Sivitz WI, Baranetsky NG, Clark SA, Waite A, Deluca HF. Cellular mechanisms of insulin release: the effects of vitamin $\mathrm{D}$ deficiency and repletion on rat insulin secretion. Endocrinology. 1983;113:1511-1518.

10. Kadowaki S, Norman AW. Dietary vitamin D is essential for normal insulin secretion from the perfused rat pancreas. J Clin Invest. 1984;73:759766.

11. Tanaka Y, Seino Y, Ishida M, Yamaoka K, Yabuuchi H, Ishida H, Seino S, Seino $\mathrm{Y}$, Imura $\mathrm{H}$. Effect of vitamin D3 on the pancreatic secretion of insulin and somatostatin. Acta Endocrinol (Copenh). 1984;105:528-533.

12. Alpdemir M, Alpdemir MF. Vitamin D deficiency status in Turkey: a meta-analysis. Int J Med Biochem. 2019;2:118-131.

13. Bhanubhai PV, Raushan B, Acharya LD, Shubha S. Assessment of quality of life in type II diabetic patients using the modified diabetes quality of life (MDQoL)-17 questionnaire. Braz J Pharm Sci. 2017;53:e17144.

14. Bahendeka S, Wesonga R, Mutungi G, Muwonge J, Neema S, Guwatudde D. Prevalence and correlates of diabetes mellitus in Uganda: a populationbased national survey. Trop Med Int Health. 2016;21:405-416.

15. Park JH, Moon JH, Kim HJ, Kong MH, Oh YH. Sedentary lifestyle: overview of updated evidence of potential health risks. Korean J Fam Med. 2020;41:365-373.

16. DeLuca HF. The metabolism and functions of vitamin D. Adv Exp Med Biol. 1986;196:361-375.

17. Cashman KD, Dowling KG, Škrabáková Z, Gonzalez-Gross M, Valtueña J, De Henauw S, Moreno L, Damsgaard CT, Michaelsen KF, Mølgaard C, Jorde R, Grimnes G, Moschonis G, Mavrogianni C, Manios Y, Thamm M, Mensink GB, Rabenberg M, Busch MA, Cox L, Meadows S, Goldberg G, Prentice A, Dekker JM, Nijpels G, Pilz S, Swart KM, van Schoor NM, Lips P, Eiriksdottir G, Gudnason V, Cotch MF, Koskinen S, LambergAllardt C, Durazo-Arvizu RA, Sempos CT, Kiely M. Vitamin D deficiency in Europe: pandemic? Am J Clin Nutr. 2016;103:1033-1044.

18. Pittas AG, Lau J, Hu FB, Dawson-Hughes B. The role of vitamin D and calcium in type 2 diabetes. A systematic review and meta-analysis. $J$
Clin Endocrinol Metab. 2007;92:2017-2029.

19. Moharir G, Naikawadi AA, Patil J, Bhixavatimath $P$, Bharatha A. Effect of vitamin don blood sugar, HbA1c and serum insulin levels in streptozotocin-induced diabetic rats. Maedica (Bucur). 2020;15:327331.

20. Scragg R, Sowers M, Bell C; Third National Health and Nutrition Examination Survey. Serum 25-hydroxyvitamin D, diabetes, and ethnicity in the third National Health and Nutrition Examination Survey. Diabetes Care. 2004;27:2813-2818.

21. Shah IU, Sameen A, Manzoor MF, Ahmed Z, Gao J, Farooq U, Siddiqi SM, Siddique R, Habib A, Sun C, Siddeeg A. Association of dietary calcium, magnesium, and vitamin $D$ with type 2 diabetes among US adults: National Health and Nutrition Examination Survey 2007-2014-A cross-sectional study. Food Sci Nutr. 2021;9:1480-1490.

22. Al-Daghri NM, Alkharfy KM, Al-Othman A, El-Kholie E, Moharram O, Alokail MS, Al-Saleh Y, Sabico S, Kumar S, Chrousos GP. Vitamin $D$ supplementation as an adjuvant therapy for patients with T2DM: an 18-month prospective interventional study. Cardiovasc Diabetol. 2012;11:85.

23. Rigo J, Pieltain C, Viellevoye R, Bagnoli F. Calcium and Phosphorus Homeostasis: Pathophysiology. In: Buonocore G, Bracci R, Weindling M. Neonatology. Springer, Cham, 2018.

24. Ditzel J, Lervang HH. Disturbance of inorganic phosphate metabolism in diabetes mellitus: temporary therapeutic intervention trials. Diabetes Metab Syndr Obes. 2009;2:173-177.

25. Winiarska A, Filipska I, Knysak M, Stompór T. Dietary phosphorus as a marker of mineral metabolism and progression of diabetic kidney disease. Nutrients. 2021;13:789.

26. Manjunath K, Christopher P, Gopichandran V, Rakesh PS, George K, Prasad JH. Quality of life of a patient with type 2 diabetes: a cross-sectional study in rural South India. J Family Med Prim Care. 2014;3:396-399.

27. Bosić-Zivanović D, Medić-Stojanoska M, Kovacev-Zavisić B. [The quality of life in patients with diabetes mellitus type 2]. Vojnosanit Pregl. 2012;69:858-863.

28. Thommasen HT, Zhang W. Health-related quality of life and type 2 diabetes: a study of people living in the Bella Coola Valley. BC Med J. 2006; 48:272-278. 